Supporting Information

\title{
Effects of Root Extract of Morinda officinalis in Mice with High-Fat-Diet/Streptozotocin-Induced Diabetes and C2C12 Myoblasts Differentiation
}

Piao Wang, ${ }^{\dagger}$ Yi Liu, ${ }^{\dagger}$ Tong Zhang, ${ }^{\dagger}$ Cheng Yin, ${ }^{\dagger}$ Seok Yong

Kang, ${ }^{\ddagger}$ Su Jin Kim, ${ }^{\mathbb{N}}$ Yong-Ki Park, ${ }^{\dagger, \neq}$ and Hyo Won Jung ${ }^{\dagger, \neq}$

†Department of Herbology, College of Korean Medicine, Dongguk University, 38066, Gyeongju, Korea

$\ddagger$ Korean Medicine R\&D Center, Dongguk University, 38066,

Gyeongju, Korea

IDepartment of Anesthesiology and Pain Medicine, College of Medicine, DonggukUniversity, 38066, Gyeongju, Korea. 


\section{Supporting Information}

\section{S1. Cell Viability Assay}

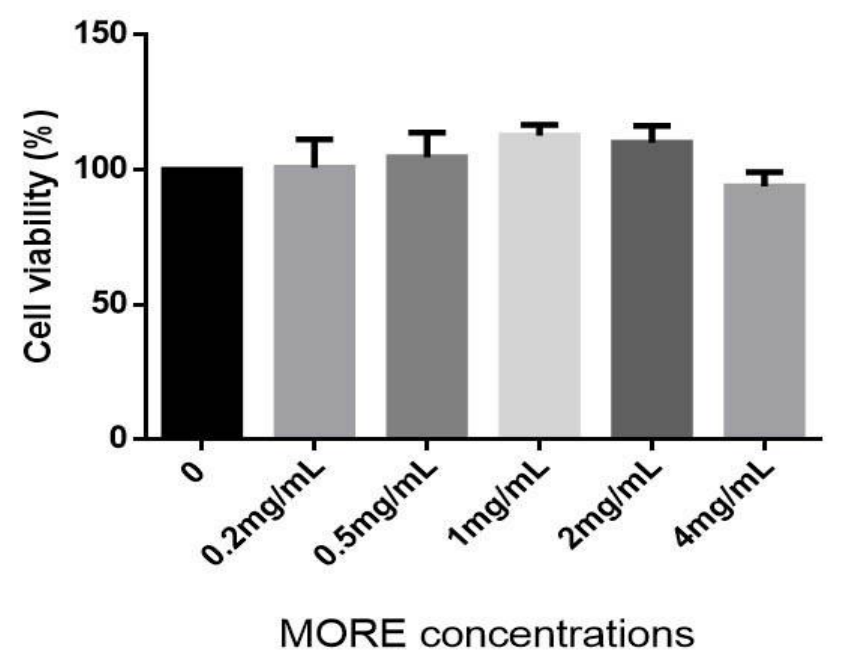

Figure S1. Effects of MORE on the viability of $\mathrm{C} 2 \mathrm{C} 12$ cells.

C2C12 myoblasts were seeded into 24-well culture plates $\left(1 \times 10^{6}\right.$ cell/well) in DMEM with $10 \%$ FBS and then treated with MORE at different concentrations $(0.2,0.5,1,2$, and 4 $\mathrm{mg} / \mathrm{mL}$ ) for $24 \mathrm{~h}$. The MTT solution was added and incubated for $4 \mathrm{~h}$ at $37^{\circ} \mathrm{C}$ in a $5 \% \mathrm{CO}_{2}$ incubator. The cell viability was measured at $450 \mathrm{~nm}$ using a microplate reader. In MTT assay, MORE did not affect the cell viability at $0.5,1$, and $2 \mathrm{mg} / \mathrm{mL}$.. 